\title{
Strategic CSR Assets within SMEs: A Comparative Case Study
}

\author{
Elise Bonneveux ${ }^{1}$, Isabelle Calmé ${ }^{1} \&$ Richard Soparnot ${ }^{2}$ \\ ${ }^{1}$ Institut d'Administration des Entreprises, Université de Tours, France \\ ${ }^{2}$ Groupe ESCEM, Tours, France \\ Correspondence: Richard Soparnot, Groupe ESCEM, Tours, France. E-mail: rsoparnot@escem.fr
}

Received: November 1, 2011 Accepted: April 1, 2012 Online Published: July 1, 2012

doi: 10.5539/ibr.v5n7p38 URL: http://dx.doi.org/10.5539/ibr.v5n7p38

\begin{abstract}
This article aims to show the extent to which strategic organizational resources and assets may determine the type of CSR strategy deployed in SMEs. It is based on the Resource Based View (RBV) approach that allows the authors to propose a theoretical grid to analyse CSR commitment considering the assets mobilized. We have conducted interviews with two SME chief executives with a view to assessing their perception of both internal and external challenges involved in corporate responsibility policy-making, and then have examined the measures implemented in their firms as well as the resources mobilized. We conclude that although the firms have similar resources at their disposal, they actually demonstrate quite different levels of commitment to responsibility in practice.
\end{abstract}

Keywords: CSR, SME, RBV approach, strategic assets

\section{Introduction}

The fact that corporate enterprises need to take ecological and social expectations into account in matters of strategic management has been amply demonstrated and confirmed by several research studies (Donaldson \& Preston, 1995; Shrivastava \& Hart, 1996; Hart, 1997; Reynaud, 1997; Reynaud \& Rollet, 2001; Martinet \& Reynaud, 2001, 2004; Reynaud et al., 2006). These studies also demonstrate that there is a certain amount of choice offered to the business world in the way responsible strategy can actually be implemented in practice (Carroll, 1979; Rugman \& Verbeke, 1998; Martinet \& Reynaud, 2004; Sharma \& Vredenburg, 1998). In reality, a wide variety of CSR strategies actually exist. These range from complete absence of policy reflecting a very negative approach to the issue, through to indifference, and at the other end of the scale, a proactive approach which attempts to anticipate and even shape environmental demands (Sharma \& Vredenburg, 1998; Azzone \& Bertelè, 1994). In the case of SMEs, various studies have looked at a selection of responsible practices (Schneider-Maunoury, 2000; Observatory of European SMEs, 2002; CROCIS-CCIP (Regional Centre for Observation of Commerce \& Industry based in the Ile de France), 2003; Berger-Douce, 2005; Quairel \& Auberger, 2005a; AFCI-CCI, 2006; Berger-Douce, 2006, 2008). This range of contrasting responses e.g. CSR measures barely integrated into overall policy versus militant SMEs which place CSR at the very heart of their strategic planning - has formed the basis of numerous research works carried out to identify the main reasons which motivate SMEs to commit to responsible policy-making.

The latter are brought together and summarized in a recent theoretical study undertaken by Aka and Labelle, 2010. According to this study, individual, organizational and institutional factors explain commitment to responsible policy-making within SMEs and in relation to individual factors, matters such as gender, age, educational level and personal values of the head of the firm are all mentioned. At the organizational level, it would appear that size, economic performance and how long the business has been in operation are important factors. At the institutional level, the determining factors relate to localization, industry sector, structure of ownership and control within the business as well as professional network links.

In any event, even if these factors explain the reasons for commitment to responsible management on the part of SMEs, they only partially explain the actual form this commitment takes. Previous studies therefore have only relative relevance when it comes to understanding the multiplicity of CSR practices actually in use in the SME sector. It is for this reason that we have adopted a Resource Based View (RBV) approach. This approach seems 
to us to be vital to gain a proper understanding of why a particular strategy might be chosen and adopted. Our hypothesis is generally that the overall availability of assets and resources an SME has at its disposal will determine the type of CSR strategy deployed. At the same time, our study aims to reveal the particular assets required for the implementation of particular CSR strategies. Furthermore, we hope that this will increase understanding of the role played by these assets in the adoption of a particular CSR strategy. Finally, we hope to demonstrate that whether a company might be more inclined to adopt a particular CSR strategy would specifically depend on whether or not they had particular assets at their disposal.

We have chosen to present out study in three parts. In the first part we discuss the most common CSR policies in practice and propose a typology of assets and resources based on the RBV approach. At the end of this section we produce a theoretical analysis grid. The second part looks at the choice of methodology used to carry out our research as well as case study analysis. The results of these case studies are then analyzed using the theoretical analysis grid. Finally, in the third part we discuss and develop the results of our study. In the conclusion we consider the main ideas, discuss them and suggest how they can be followed up in a future research program.

\section{CSR Strategies within SMEs \& the RBV Approach}

This section is developed in two ways. The first deals with different CSR strategies within SMEs whereas the second puts forward a typology of assets based on the RBV approach. At the end of this dual analysis we produce our results in the form of a theoretical analysis grid.

\subsection{Diversity of CSR Strategies within SMEs}

A study of 7600 SMEs carried out by the European Commission in 2002 revealed that half of the SMEs interviewed claimed to have responsible strategies actively in place. These results are confirmed by a study of SMEs in the Ile de France area of Paris (CROCIS-CCIP, 2003): namely that 59\% of businesses approached said that they included sustainable development in their management planning. Finally, another study carried out amongst SMEs in the Rhône-Alpes area demonstrated that 92.5\% of SMEs had adopted responsible management in their businesses (AFCI-CCI, 2006). Although these results are encouraging (between 50 and 90\% of SMEs demonstrating commitment to social and/or ecological issues), these results need to be carefully examined (Quairel \& Auberger, 2005b). In fact, it would appear that responsibility within SMEs is characterized more by one-off measures or initiatives than by any truly structured or integrated policy (Berger-Douce, 2008). The study produced by the European Observatory demonstrates that the majority of SMEs which are socially and ecologically engaged carry out sponsorship locally such as community initiatives "outside-work hours" which although not un-useful in themselves are nonetheless measures unconnected to the business activities of the company in question. Finally, evidence of successful transfer of theory into actual practice remains limited. For instance, very few SMEs actually have a formal structured policy (e.g. strategy) in place between themselves and other stakeholders and/or have adopted standardized evaluation and monitoring tools adapted for use in SMEs. As Berger-Douce (2008) highlights in relation to responsible practices in the SME sector "there is probably a gap between theory and practice”. However, other studies carried out on more restricted sample groups suggest that some SMEs (approx a thousand of them) have placed sustainable development at the very heart of their decision-making process (Berger-Douce, 2008). It is a very different picture in the case of some pioneering SMEs (Schneider-Maunoury, 2000; and Berger-Douce, 2005, 2006). These companies are more actively committed, and, despite a variety of obstacles such as lack of resources, incentives, time and support (Berger-Douce, 2005, 2006) they still manage to implement responsible policy (Schneider-Maunoury, 2000; Berger-Douce, 2005, 2006).

In order to examine the variety ofdifferent responsible CSR practices in use, academic research literature has come up with several typologies (Carroll, 1979; Sharma \& Vredenburg, 1998; Azzone \& Bertelè, 1994; Reynaud \& Chandon, 1998; Belling, 2003). Examination of the literature also highlights that whereas for some businesses, sustainable development is synonymous with costly and restrictive requirements, others are able to assimilate socially and ecologically responsible ideas and see sustainable development as a source of opportunity to create and add value (Schneider-Maunoury, 2000; Reynaud \& Rollet, 2001; Persaix, 2002). Whereas some are able to adapt to the constraints of a particular sector (legal pressure at both local and national level) which enables them to adjust to the demands being made on a social and ecological level, others seek actively to anticipate legal and administrative requirements and are able, as a matter of choice, to go beyond what is strictly required of them.

In this study we have applied the Bellini classification (2003), inspired itself by the work of Carroll (1979). This classification identifies 3 dominant sustainable development traits namely the eco-defensive position, the 
eco-conformity position and the eco-sensitive position. Each particular behavior type is characterized by the decisions it makes in terms of resource allocation (whether in the ecological, social, community or economic domain) which is linked, in turn, to the adoption of a decision-making model which challenges the dominant decision-making logistics of the business - to a greater or lesser degree (Bellini, 2003).

The eco-defensive position is characterized by the exclusive prioritization of the pursuit of profit and immediate economic return. This behavior type tends to think of ecological and social investment as wasteful and costly and also at odds with the economic dynamic. The eco-defensive position is therefore one of maintaining current business practices without integrating either ecological or social considerations into management planning (at the risk of breaking the law). This position has become increasingly rare because the risks (financial or other) associated with breaching administrative regulations have become increasingly more significant.

The eco-conformist position is characterized by conformity to the law, respect for rules and administrative regulations but is limited to doing only that which is legally required, so as to avoid breaking the rigorous laws in place. The eco-conformity position seeks to minimize risk and investment by operating within legal norms. The prime objective of this behavioral type lies in the desire to maintain optimum profits all the while safeguarding the legitimacy of its activities in relation to its stakeholders. Steps taken towards responsible management are considered to be more of a damage limitation exercise in relation to risks generated by this area. For this type of business, responsibility creates technical and organizational constraints, and incurs additional costs associated with adaptation and it does not create value.

On the other hand, the eco-sensitive position does not emphasize immediate financial return. Social and ecological investment produces longer term results. This type of business sees ecological and social investment as viablefor a business in the medium to long term. Most often they exceed regulatory standards imposed by law. Nor do they always wait for a law to be actually passed before introducing environmental or social development policies into their management practices. Corporate responsibility issues are considered to be key elements of continuity and growth for a business and are at the very heart of strategic policy making. The objective is two-fold. On the one hand sustainable development generates benefits in terms of expenditure (reduction in costs of production in the long term), legitimacy (image projected to stakeholders, workplace culture...) and market differentiation (quality of products, eco-labellization...) (Reynaud \& Rollet, 2001; Reynaud \& Martinet, 2004). On the other hand, the business operates in the hope of being able to influence other operators in the chain (clients, suppliers and sometimes competitors). The aim of this group is to push at the boundaries of doing business to bring about changes which appeal both ethically and economically. Establishing new rules for development and obliging competitors to play a game they are a bit unsure of is one of the objectives of pro-active promotion of corporate responsibility (Sharma \& Vredenburg, 1998).

Categorization of responsible behavior by type allows us to set out the basis upon which our analysis of CSR strategies within SMEs can be carried out. (Table 1)

Table 1. CSR strategies within SMEs

\begin{tabular}{lccc}
\hline CSR strategies & Eco-defensive & Eco-conformist & Eco-sensitive \\
\hline Characteristics & 1-Positioned just within & 1-Complies with regulatory standards & 1-Goes beyond regulatory standards \\
and evaluation & regulatory norms & 2-Deploys responsible policies and & 2-Deploys structured, formalized \\
& 2-Deploys no responsible & practices on non-formal lines & responsible policies and practices \\
& policies or practices & 3-Allocates similar resources to SD as & 3-Allocates more resources to SD \\
& 3-Allocates no resources for SD & its average competitor & than its average competitor \\
\hline
\end{tabular}

In the following section we take a quick look at RVB. Bearing in mind the nature of this study, particular attention is paid to the asset typology.

\subsection{RBV and Identification of Asset Typology}

For exponents of RBV (Wernerfelt, 1984; Barney, 1991), the performance of a firm and its adoption of strategy depend on its assets. They believe that company strategy will be more successful if it is based on assets at the disposal of the firm. In other words, the choice of strategy depends hugely on assets available to it. 
The whole notion of the term assets needs to be addressed and the meaning clarified. In order to do this we have elected to use the 3 following categories of assets: resources, capacity and aptitude.

Resources are ways in which a firm is able to transform input into output and which are attached to it e.g. which the firm possesses and can control. Wernerfelt (1984) makes the distinction between tangible resources (financial, physical, technological and organizational) and intangible resources (culture, relationships, reputation, legitimacy...). These resources can be conceptualized as stocks and shares the accumulation of which depends on the intensity and the rhythm of investments successfully carried out by the firm (or flow of financial resources such as the cost of Research and Development, advertising, personnel training...) (Dierickx \& Cool, 1989). However, resources are rarely productive in themselves, they only represent potential. In fact, even though they are very important for the successful production of a firm's output, they are a necessity, yes, but not sufficient in themselves to produce output. In fact resources only become real at the point at which they are mobilized in a process in order to carry out a specific function. The concept of capacity permits a better understanding of the way resources work.

Taking the base-line definition of capacity as described by Amit and Shoemaker (1993), we believe that capacity can be defined as the ability of an organization to implement the deployment, combination and coordination of resources throughout a process of actions in order to implement strategic objectives defined in advance. Lamarque (2001) also notes that "competence is defined as the capacity to implement a task or an activity as a result of resources available to carry it out. It involves a combination of the latter in accordance with organizational processes and collective savoir-faire". So, competence is the direct result of resource input. Resources make up the "elementary particles" of competence (Métais, 2003). It is important to note that the grouping of resources would be specific to a particular firm. In fact, not all companies deploy resources in the same way. As a result, organizational capacities depend upon the history of the firm and its development over the years as these factors create a heritage which will determine future development. This phenomenon is known as path dependency.

We consider that there are two different types of organizational capacity. The first is operational in that it enables a firm to exercise its current activities connected to the day-to-day running of the business. The second is dynamic in that it enables creation and design and renewal and evolution of a firm's assets ensuring its adaptation to the never-ending changes which characterize the market environment (Teece et al., 1997; Eisenhardt \& Martin, 2000; Zollo \& Winter, 2002).

In any event, no matter what the nature of a firm's capacity (operational and oriented towards short-term returns or dynamic and oriented towards the long term), it only exists if it is translated into action. In other words, it only becomes effective, only becomes real from the point at which it is expressed, e.g. put into action in order to obtain a particular result. So, until capacity takes on active form, it can only be considered to be an aptitude, e.g. a capacity in the making, and only exists in a latent form within an organization.

These theoretical discussions enable us to construct an analytical framework for the examination of assets with potential to be used by SMEs as part of management planning with a view to adoption and deployment of a CSR strategy.

Examination of CSR strategies within SMEs enables us to put forward 3 main options: the eco-defensive position, the eco-conformist position and the eco-sensitive position. Following on from this, asset analysis enables us to identify 3 main types of asset: resources, capacity and aptitude. The table below presents our analytical case-study model.

Table 2. Analysis model of assets required for CSR within SMEs

\begin{tabular}{|c|c|c|c|c|}
\hline & & Eco-defensive & Eco-conformist & Eco-sensitive \\
\hline \multirow[t]{2}{*}{ Resources } & Tangible & & & \\
\hline & Intangible & & & \\
\hline \multirow[t]{2}{*}{ Capacity } & Operational & & & \\
\hline & Dynamic & & & \\
\hline Aptitudes & & & & \\
\hline
\end{tabular}


In the following part of our study we reveal the methodological choices we have elected to use as well as analysis of the case studies conducted.

\section{Research Methodology and Case Study Presentation}

There are two parts to discussion of our empirical methods. Firstly we will demonstrate the methodological choices used in our study. Then we will go on to discuss the cases themselves which form the subject of our research studies.

\subsection{Methodology Used in Study}

Our research paper is undertaken as a qualitative study for exploratory purposes (Yin, 1989; Wacheux, 1996). We are trying to establish whether assets used by a firm influence the adoption of responsible behaviors. The exploratory nature of our study explains why we chose to study several cases. Since our aim is to identify recurrent behavioral phenomena it seemed appropriate therefore to conduct research into several firms (Eisenhardt, 1989; Yin, 1989).

We conducted a series of interviews with two SME directors both working in the same industry sector - the metal industry and in the same geographical area in France (Indre-et-Loire). By doing this we were in a position to see that, within the same sector, firms have to confront exactly the same type of problem e.g. effective control of resources and the effect this then has upon commitment to CSR within a SME. These 2 particular SMEs were selected because of the difference in approach they demonstrated towards commitment to CSR. Data collection was carried out by way of semi-directive, one-to-one interviews of about an hour and a half each throughout the period September to December 2010.

In the case of each company, our study focused on the path forged by the director in relation to the main subject areaslisted below, the action then taken by the firm and the methods used. What was involved here was an assessment of the reasons which motivated directors to commit to themselves to a particular course of action; and from there an examination of the type of resources mobilized by the firm as well as the processes or interactions involved in bringing a pre-determined course of action to successful conclusion. We designed a table to illustrate the structure of our interviews which were grouped around the following themes:

- Director's view of challenges linked to the metal industry sector,

- Director's view of SD in the sector,

- Strategic orientation preferred,

- Main action taken and long-term direction fully researched,

- Resources mobilized and organizational methods implemented to support actions/measures taken.

The data collected have been analyzed thematically (Bardin, 1998). A first round of analysis demonstrates the degree of intensity of a company's commitment to CSR. Secondly, the data was then interpreted using the analytical model used in our theoretical framework. We then went on to explain the differences in intensity of commitment to CSR recorded in relation to resources mobilized by the firms involved. This second round of analysis enabled us to characterize more effectively the organizational capacities which help drive CSR behavior.

\subsection{Presentation of Companies Studied}

For the purposes of this study, investigations were carried out in two SMEs in the capital goods industry (a sub sector of the metal industry) in the Indreet Loire region of France. The results are presented in the table below:

Table 3. Indicative characteristics of companies interviewed

\begin{tabular}{|c|c|c|c|c|c|}
\hline & Main business activity & $\begin{array}{l}\text { Year business } \\
\text { started }\end{array}$ & Legal status & $\begin{array}{l}\text { Number of salaried } \\
\text { employees }\end{array}$ & $\begin{array}{l}\text { Commercial sphere } \\
\text { of operation }\end{array}$ \\
\hline PME 1 & $\begin{array}{l}\text { Construction of railroad machinery for } \\
\text { maintenance of infrastructure }\end{array}$ & 1965 & Plc. & 80 & International \\
\hline PME 2 & $\begin{array}{l}\text { Development and manufacture of } \\
\text { made-to-measure stainless steel furniture }\end{array}$ & 1994 & $\begin{array}{l}\text { Simplified joint } \\
\text { stock company }\end{array}$ & 35 & National \\
\hline
\end{tabular}


The CSR behavior of each SME is presented in the following tables which summarize information provided by the two directors as to their perception of CSR and its implementation.

Table 4. CSR strategy of SME 1, company perception of CSR, action taken and resources mobilized

\begin{tabular}{|c|c|}
\hline $\begin{array}{l}\text { Perception of challenges related } \\
\text { to the metal industry sector }\end{array}$ & $\begin{array}{l}\text { here are difficult issues in the sector which arise as a result of legislation and clients who fix } \\
\text { eecifications and impose terms and conditions. Clients both national and international. }\end{array}$ \\
\hline Perception of CSR in the sector & $\begin{array}{l}\text { "Sustainable development has become more and more of a constraint which forces a fair few } \\
\text { businesses to drop investment in favor of contracting out." }\end{array}$ \\
\hline Strategic orientation preferred & $\begin{array}{l}\text { Company wants to increase its visibility in the area of restoration and remotorization of railroad } \\
\text { machinery. }\end{array}$ \\
\hline $\begin{array}{l}\text { Main action taken in different } \\
\text { CSRcategories }\end{array}$ & $\begin{array}{l}\text { On the environmental side, the business has been accredited with ISO } 9001 \text { certification since } 2006 . \\
\text { This step was taken in response primarily to client demand (notably the SNCF (1) which is an } \\
\text { important client for the company). The company is also involved in an incentive program initiated by } \\
\text { the SNCF to create a hybrid locomotive demonstrator. } \\
\text { In relation to waste, the company complies with legal requirements. It recycles and treats waste using } \\
\text { local partners. } \\
\text { In relation to social commitment, measures taken are in line with the size of the company, regulatory } \\
\text { requirements and with other business practices in the sector. It has started a company savings scheme } \\
\text { and a profit-share scheme. } \\
\text { On the economics side, the firm is looking to maximize its costs in order to maintain turnover. In order } \\
\text { to do this it regularly uses temporary staff. } \\
\text { In relation to community links, the firm contributes according to its means and wherever it can by the } \\
\text { transference of skills and know-how to young apprentices. This is a way for the director to participate } \\
\text { and be involved in the development of the local economy. }\end{array}$ \\
\hline Resources mobilized/utilized & $\begin{array}{l}\text { Tangible resources } \\
\text { Significant financial resources ( accumulation of reserves) } \\
\text { Software system: CAD 3D Solid Edge } \\
\text { Engineering and Design office } \\
\text { IS0 } 9001 \text { Certification (since 2006) } \\
\text { Intangible resources } \\
\text { Technical know-how and expertise in boiler-making industry } \\
\text { Technical know-how and expertise in hybrid solutions in the metal industry sector } \\
\text { Very good reputation and links with SNCF } \\
\text { Contacts with various overseas partners } \\
\text { Overseas operating license } \\
\text { Relations with various different sub-contractors }\end{array}$ \\
\hline
\end{tabular}

(1) SNCF: Société Nationale de Chemin de Fer (National RailwayCompany). 
Table 5. CSR strategy of SME 2, perception of CSR, action taken and resources mobilized

\begin{tabular}{|c|c|}
\hline $\begin{array}{l}\text { Perception of challenges related } \\
\text { to the metal industry sector }\end{array}$ & $\begin{array}{l}\text { Clients of this SME are restaurant chains, the supermarket distribution sector, those involved in the } \\
\text { installation of professional kitchen equipment and the resale market, laboratories, indoor and outdoor } \\
\text { markets and specialized shops. } \\
\text { The business works on the basis of mutual trust. There are no specifications or terms and conditions } \\
\text { imposed by clients. }\end{array}$ \\
\hline Perception of CSR in the sector & $\begin{array}{l}\text { "It is important to carry out energy efficient and energy saving policies, to improve the comfort of } \\
\text { personnel...there is going to be more and more legislation in relation to SD and I think that we should } \\
\text { go with this and look for solutions so that construction is less expensive." }\end{array}$ \\
\hline Strategic orientation preferred & $\begin{array}{l}\text { To maintain turnover figures (since 2004, turnover has increased steadily from } 2.8 \text { million to } 5 \text { million } \\
\text { Euros). }\end{array}$ \\
\hline $\begin{array}{l}\text { Main action taken in different } \\
\text { CSR categories }\end{array}$ & $\begin{array}{l}\text { On the environmental side, the firm has not opted for any particular certification, believing this is not } \\
\text { necessary currently. However, in relation to the expansion of its operation, building work was carried } \\
\text { out in line with HQE (Haute QualitéEnvironmentale - French environmental certification) } \\
\text { requirements and the firm plans to install solar panels. } \\
\text { In relation to waste, the company has been fully compliant with regulatory requirements for some } \\
\text { considerable time now. It recycles and treats waste with local partners. } \\
\text { In relation to social commitment, measures taken are in line with the size of the firm and regulatory } \\
\text { requirements. It provides an automatic bonus scheme (14 months of salary) to its employees and has } \\
\text { been involved in several initiatives to improve working conditions for its staff. } \\
\text { On the economics side, the firm is financially pretty healthy showing steady increase in both turnover } \\
\text { and workforce numbers. Investment in a laser machine appears to have contributed significantly to the } \\
\text { company's increase in turnover. } \\
\text { In relation to community links, the firm contributes according to its means and wherever it can by the } \\
\text { transference of skills and know-how to young apprentices. }\end{array}$ \\
\hline Resources mobilized & $\begin{array}{l}\text { Intangible resources } \\
\text { Financial resources (accumulation of reserves) } \\
\text { Mentoring and professional development training } \\
\text { Laser machine with 3D software } \\
\text { Automated design office } \\
\text { Intangible resources } \\
\text { Savoir-faire and expertise in the boiler-making industry } \\
\text { Involvement in the business working group/cluster - the Membership of network - Groupement des } \\
\text { Entreprises du Val d'Amboise (GEIDA) } \\
\text { Membership of the Metal industry and Metal workers Union (UIMM) }\end{array}$ \\
\hline
\end{tabular}

\section{Analysis of CSR Behavior: Action Undertaken, Measures Implemented, Resources Mobilized and Capacities Deployed}

We start by offering a comparative analysis of the cases studies. This will reveal (by way of analysis of the resources adopted) the differences between the two firms in terms of commitment to responsible policy-making, perception of challenges presented by CSR and then finally measures implemented. Secondly, we present an interpretative examination of the concepts mobilized by the firms, using the RBV approach, which will enable us to explain in greater detail the differences in commitment we discovered. Finally in relation to the combined assets of the firms studied, we will attempt to understand whether the difference in terms of commitment to CSR can be explained by specific organizational capabilities.

\subsection{Similar Resources but Different Level of Commitment to Corporate Responsibility}

In many ways, the 2 companies which are the subject of our case study have much in common. They both operate in the metal/sheet metal industry sector and have expertise in the boiler-making industrial sector. Even 
though they have specialized in specific applications and developed different strategic activities, they have resources at their disposal which are roughly comparable. They both have engineering and design offices for the development of new products. The personnel employed by both firms are well qualified, whether they are workers on the shop floor, management or engineers. In relation to intangible resources, both firms have a very good reputation amongst clients for both the quality of their product and their business responsiveness. They both belong to professional associations such as GEIDA and UIMM. Membership of these associations gives them access to information relevant to developments in the sector as well as information about regulations generally whether they are environmental, social or technical in nature. These associations also offer management training opportunities to its members as well as training to increase understanding of and sensitivity to corporate responsibility issues.

However, although the two companies do have a number of things in common and the same access to a similar number of resources, our results show a marked difference in the manner in which sustainable development is perceived by the 2 directors (the future of SD in the sector and the pressure exerted by clients, compliance with regulations...) and in the measures implemented by them. As tables 4 and 5 illustrate the priority accorded to the different areas of CSR are very dissimilar.

With reference to the matrix set out in the first section of our paper (table 1) which distinguishes between the level of integration of environmental standards in relation to how internal and external challenges are perceived, it is now possible to identify responsible behavior in the two firms. In addition, based on discussions with the two directors, our results reveal two distinct types of strategy for integration of corporate responsibility - an integration strategy in line with the eco-conformity position for SME no.1 and then a more pro-active approach, which we call eco-sensitive, for SME no.2.

In relation to SME no.1 the majority of investments introduced (hybrid technology, ISO 9001 certification...) have come about as a result of strong external pressure (from clients and increased market competition). On the social and environmental front, the measures introduced are completely in line with others in the sector. The director didn't appear to be particularly convinced of the relevance of any greater commitment to responsible management, as the comments recorded below indicate.

Manager of SME 1 in relation to ISO 9001 and 14001 certification...: "I am quite skeptical... I don't believe that companies without the accreditation work badly or that all those who do actually have the accreditation work well....these days certification is indirectly imposed through the whole process of tendering for contracts...In relation to ISO 14001, we had to give the matter some thought...because we had submitted tenders to EDF(Electricité de France, French Electric Utility Company) and they had asked us where we were up to with the accreditation process and we see increasingly that reference to SD have now started to appear in tenders...but what weight does this carry in reality? Quality and price remain the determining factors...".

At the same time the firm comes up against strong financial imperatives which mean that it has to resort to using temporary staff and sub-contracting practices, and is thus forced to forego internal investment. In this regard the statement below is revealing:

Manager of SME no.1: "Sustainable development is becoming more of a reality in as much as it exerts a fair degree of pressure on businesses. In our company, we have given up making long-term investment and have increasingly taken the decision to sub-contract and outsource instead either within France or elsewhere because regulatory compliance has made itall but impossible unless you are very profitable businesses....compliance has become increasingly burdensome and given our market price it has become prohibitive so we are tending more and more to stick to assembly...".

For the reasons outlined above, responsible behavior in SME no.1 means minimal incorporation of CSR in reality, in line with conformist strategy.

The commitment to social responsibility shown by SME no.2 is in a very different league and is much more in line with a pro-active incorporation strategy (eco-sensitivity). On the environmental front in particular, measures taken have not been forced upon the company in reaction to particular external pressures but have been undertaken more as a preventative in anticipation of legislation but equally in response to internal needs (improvement of working conditions for example). The following extracts illustrate this difference in perspective:

Director of SME 2: "Sustainable development within business can only develop because there is more and more legislation in the area which means that ...we just have to comply and get on with it... As for me personally, every time I need to buy a new machine or product or think about expanding the business, I feel the need to 
check and see what regulation or the other I need to think about. I think this is going to become really important from now on and that's what I think we have to consider first."

Going beyond these first impressions and comparisons, we now need to examine the question of whether or not these different reactions to corporate responsibility involve a particular combination of specific assets.

\subsection{Identification of Organizational Capacities Likely to Encourage Adoption of Corporate Responsibility Strategies}

As indicated above, commitment to CSR in SME no.1 is limited. We noted an accumulation of assets in relation to hybrid technical know-how and in the manufacture of machinery used for railroad maintenance. The company has in fact developed knowledge in this area through its engineering and design office as well as the accumulated experience it has gained over time and finally as a result of contacts it has been able to develop with the SNCF. This accumulation of resources has led the business to concentrate the focus of its business activity on the design of rail machinery and the restoration of traction engines. This has enabled it to acquire specific competence in the area of hybrid motorization, and this is recognized professionally in the sector. In terms of its commitment, the firm doesn't make any particular distinction between the environmental, social or community sectors of responsibility. The firm certainly has resources and has developed its competence across different responsibility sectors as is reflected in the measures it has implemented - highlighted in table 4 (company savings scheme, profit share...), in its commitment to the community (apprenticeships) and to the environment (waste treatment). However, it does only the minimum which is legally required of it. It doesn't seem to have a global appreciation these different assets can have for a business. Measures implemented in environmental, social and community sectors of responsibility do not appear to have brought value added for the firm. Even the firm's membership of various different professional organizations has not been the trigger for the uptake of additional responsible measures or initiatives. Membership itself has not materialized into specific action. The aim of SME no.1 would appear to be securing an optimization of costs and consolidation of its market position with its main clients. In order to do this it has switched its knowledge base to the areas of design and assembly in the machine engine sector and has invested in specific CAD software for the purpose. As a result, the firm's horizons are limited to the short term. In reality what this means is a reduction of assets used for production and manufacture, and the use of resources for maintenance of specific capabilities in the area of design and assembly of railroad machinery instead - the sole objective of which is to respond to external requirements (compliance with legislation and client demands) and to optimize organizational productivity.

Commitment to corporate responsibility outlined above in the case of SME no.1 in reality means the development of capabilities which are essentially operational in nature and focused on maintaining productivity and the day-to-day working of the business.

However, in the case of SME no.2, the resources used and the manner in which they are deployed in reality reveal an entirely different state of affairs. Just like the case of SME no.1, SME no. 2 has accumulated knowledge and practical skills in the boiler-making industry acquired through experience and the work carried out in its engineering and design office, and as a result of specializing in a particular strategic business activity e.g. the manufacture of stainless steel furniture aimed at the professional market. Over the years SME no.2 has acquired a very good reputation with its clients to the point where relations with its business partners are based on mutual trust and not on the particular requirements or whim of a company director. In relation to the different CSR sectors, SME no.2 has adopted a few of theresources and assets e.g. on the environmental front (research conducted into environmental standards) and in relation to social responsibility (research conducted into sound-proofing of building, replacement of machinery by less noisy equipment, refurbishment of its warehousing facilities). In contrast to SME no.1, SME no. 2 has acquired, little by little, its own experience from the development of its assets and as a result of the professional contacts made by its director. A working example of this is the firm's membership of GEIDA and the voluntary functions it performs for the UIMM which have enabled the firm to access up-to-date information about environmental legislation and organizational audit practices. This has created the opportunity for the firm to take part in working groups on the subject of development of green construction practices in line with HQE standards as well as on the subject of dissemination of information and resources in order to implement collective sustainable development measures within the network. The director of SME no.2 was also invited to take part in an environment commission (organized through GEIDA) the role of which was to select one or several businesses in the region to establish financially attractive partnership deals for the members of the network. Membership of the network also inspired and enabled him to carry out an organizational audit of his own company. As a result, various different measures were implemented and action taken. For instance the firm ensured that new office buildings were HQE compliant, it improved working conditions in the production workshops by replacing old machinery with new 
soundproofed equipment, by improving the inspection pit areas and by refurbishing various other warehouse storage facilities which included the installation of an automated warehouse storage facility. The design office has also undergone changes in that it now has the use of a new 3D CAD computer software system and an automated laser machine. These improvements have enabled the company, over time, to respond to an increasing number of demands made upon it as a result of the time-saving measures introduced in the design area and improved business responsiveness to its clients. Over a 4 year period during which the firm has gradually introduced these changes, it has in effect doubled its turnover and its workforce and has been able to offer its workers a 14 month paid salary bonus.

A dynamic environment has been created as new assets (knowledge, resources, skill set and experience) have been adopted by the company. We are of the opinion that the various measures implemented under the different CSR headings have had a beneficial effect on SME no.2. The type of responsible behavior which we described earlier as proactive, has enabled the development of a dynamic capacity which in turn has brought about the creation, renewal and development of assets relevant to the different CSR sectors, so ensuring that the firm is not only able to adapt successfully to environmental demands but that it actually anticipates and prepares for them in advance.

\section{Conclusion and Discussion}

The aim of this study was to find out whether the deployment by a firm of specific resources or capacities had any influence or effect upon the level of commitment to corporate responsibility demonstrated, and this being the case, to examine the nature of this deployment. We then went on to conduct interviews with the directors of both SMEs with a view to assessing their perception of both internal and external challenges involved in corporate responsibility policy-making, and then to examine the measures implemented in their firms as well as the resources mobilized. We concluded that although the firms had similar resources at their disposal, they actually demonstrated quite different levels of commitment to responsibility in practice.

This finding corroborates previous study of SMEs and their directors. In effect, in the SME context, access to resources which is often a difficult issue for the head of a business, is absolutely imperative if there is to be adoption and integration of CSR measures and initiatives. As demonstrated by the research of the following authors - Julien (1996), Quairel and Auberger (2005), Berger-Douce (2006), Capiez (2007), and Fourcade (2008), membership of a professional network or access to professional support enables a director to neutralize information asymmetry and to access both tangible and intangible resources more easily- all of which encourages integration of responsible measures within an organization.

Even so, these criteria are not sufficient on their own to explain the disparity in terms of commitment to responsibility. What the data collected in our study also demonstrates is that the existence of a dynamic based on the capacity to combine relevant resources or assets under the different CSR headings, contributes towards the development of a responsible strategy.

This second finding demonstrates that the dynamics of an organization are based on a process of accumulation of assets which is mirrored by the accumulation of new learning experiences on the part of a company director. It would appear that the capacity of a director to locate and integrate new resources is fundamental to the integration of CSR measures and initiatives. The latter would appear to be "a learning process during which the internal and external capacities of the firm join together in interacting with its environment" (Nicolas \& Hy, 2000). As a result, the learning capacity of directors is demonstrated by their ability to acquire information and resources whilst interacting with stakeholders. Consequently, this dynamic is very dependent upon the perception and motivation of the firm's director and how he sees and reacts to CSR issues.

This is a research area which needs to be explored further and focused on directors themselves, using comparative analytical methodology of the type set out by Paradas (2008) and Gendre-Aegerter (2008). This methodology would include for instance cognitive maps to extend research into corporate responsibility and to analyze the experience and thoughts of SME directors in this area.

\section{References}

ACFCI. (2006). La prise en compte du développement durable et de la responsabilité sociétale de l'entreprise (DD/RSE) par les PME/PMI. Octobre.

Aka, K. G., \& Labelle, F. (2010). La responsabilité sociétale des petites et moyennes entreprises ou la RSPME: une analyse de la littérature des dix dernières années. Congrès de l'Association des Sciences Administratives du Canada, Régina. 
Amit, R., \& Schoemaker, P. J. (1993). Strategic Assets and Organizational Rent. StrategicManagement Journal, 14, 33-46. http://dx.doi.org/10.1002/smj.4250140105

Azzone, G., \& Bertelè, U. (1994). Exploiting green strategy for competitive advantage. Long Range Planning, 27(6), 69-81. http://dx.doi.org/10.1016/0024-6301(94)90165-1

Bardin, L. (1998). L'analyse de contenu (9th ed.). Paris, PUF.

Barney, J. B. (1991). Firm resources and sustained Competitive advantage. Journal of Management, 17, 99-120. http://dx.doi.org/10.1177/014920639101700108

Bellini, B. (2003). Un nouvel enjeu stratégique pour l'entreprise: la prise en compte de la protection de l'environnement dans son management, Etat des lieux et perspectives. XII ${ }^{\text {ème }}$ Conférence de l'Association Internationale de Management Stratégique.

Berger-Douce, S. (2005). Management environnemental et PME: apports et limites d'une démarche collective. Revue internationale PME, 18(3-4), 93-123.

Berger-Douce, S. (2006). La démarche collective, un outil d'appropriation du management environnemental par les PME?. Revue Sciences de Gestion, 54, 1-18.

Berger-Douce, S. (2008). Rentabilité et pratiques de RSE en milieu de PME: Premiers résultats d'une étude française. Revue Management et Avenir, 15, 9-29. http://dx.doi.org/10.3917/mav.015.0009

Capiez, A. (2007). Réseaux d'entreprises et performance. Revue internationale PME, 20(1), 41-67.

Carroll, A. (1979). A Three-Dimensional Conceptual Model of Corporate Social Performance. Academy of Management Review, 4(4), 497-505. http://dx.doi.org/10.5465/AMR.1979.4498296

CROCIS-CCIP, Baromètres. (2003). Le développement durable dans les PME/PMI Franciliennes.

Dierickx, I., \& Cool, K. O. (1989). Asset Stock Accumulation and Sustainability of Competitive Advantage. Management Science, 35, 1504-1511. http://dx.doi.org/10.1287/mnsc.35.12.1514

Donaldson, T., \& Preston, L. E. (1995). The stakeholders theory of corporation: concepts, evidences and implications. Academy of Management Review, 20(1), 65-91. http://dx.doi.org/10.5465/AMR.1995.9503271992

Einsenhardt, K., \& Martin, J. A. (2000). Dynamic Capabilities: What are they?. Strategic Management Journal, 21, 1105-1121. http://dx.doi.org/10.1002/1097-0266(200010/11)21:10/11<1105::AID-SMJ133>3.0.CO;2-E

Eisenhardt, K. M. (1989). Building Theories From Case Study Research. The Academy of Management Review, 14(4), 532-550. http://dx.doi.org/10.2307/258557

Fourcade, C. (2008). Stratégies de coopération de proximité : des modes d'innovation organisationnelle en PME.

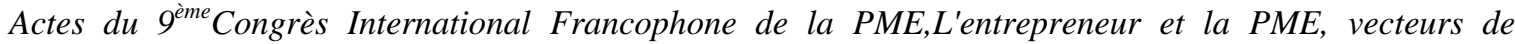
changement et d'innovation, Louvain, 29-31 octobre.

Gendre-Aegerter, D. (2008). La perception du dirigeant de PME de sa responsabilité sociale: une approche par la cartographie cognitive. Thèse présentée à la Faculté des Sciences économiques et sociales de l’Université de Fribourg.

Hart, S. (1997). Beyond Greening: Strategies for a Sustainable World. Harvard Business Review, Janvier-Février, 66-76.

Julien, P.-A. (1996). Entrepreneuriat, développement du territoire et appropriation de l'information. Revue internationale PME, 9(3-4), 149-178.

Lamarque, E. (2001). Avantage concurrentiel et compétences clés: expérience d'une recherche sur le secteur bancaire. Finance Contrôle Stratégie, 4, 63-88.

Martinet, A. C., \& Reynaud, E. (2001). Shareholders, stakeholders et stratégie. Revue Française de Gestion, Novembre-Décembre, 12-25.

Martinet, A. C., \& Reynaud, E. (2004). Stratégies d'entreprise et écologie. Paris, Economica.

Métais, E. (2003). Stratégie de l'entreprise et ressources. Paris, Edition Economica.

Nicolas, F., \& Hy, M. (2000). Apprentissage technologique et innovation en agro-alimentaire. Economie rurale, 257, 27-41.

Observatoire des PME européennes. (2002). Chapitre 9: Responsabilité sociale et environnementale.

Paradas, A. (2008). La position des petites entreprises face à la responsabilité sociale. ROR, 1, 39-52. 
Persaix, E. (2002). L’écologie comme atout stratégique: une validation de l'approche ressources par la méthode PLS. Finance Contrôle Stratégie, 5(3), 195-230.

Quairel, F., \& Auberger, M. N. (2005a). Les PME seront-elles socialement responsables?. In Dupuis, J. L. \& Le Bas, C. (Eds.), Le Management responsable, Vers un nouveau comportement des entreprises? (pp. 63-84). Paris: Economica.

Quairel, F., \& Auberger, M. N. (2005b). Management responsable et PME: une relecture du concept de responsabilité sociétale de l'entreprise. Revue des Sciences de Gestion, Direction et Gestion, 211-212, 111-126. http://dx.doi.org/10.1051/larsg:2005010

Reynaud, E. (1997). Les déterminants de comportement de protection de l'environnement des entreprises. (Thèse de doctorat nouveau régime). IAE d'Aix-en-Provence.

Reynaud, E. (Ed.) (2006). Le management durable au cœur de l'entreprise. Paris: Edition Dunod.

Reynaud, E., \& Chandon, J. L. (1998). De vert clair à vert foncé: différents types de comportements de protection de l'environnement. In Ingham, M., \& Koenig, G. (Eds.), Perspectives en Management Stratégique (pp. 223-242). Tome V, Paris: Editions Management et Société.

Reynaud, E., \& Rollet, A. (2001). Les compétences centrales "environnement" comme source d'avantages concurrentiels et de légitimité. In Martinet A.C. \& Thiétart R.A. (Eds.), Management stratégique: actualités et futurs de la recherche (pp. 303-324). Paris: Vuibert.

Rugman, A., \& Verbeke, A. (1998). Corporate strategy and environmental regulations: an organizing framework. $\begin{array}{lllll}\text { Strategic } \quad \text { Management } & \text { Journal, } & \text { 363-375. }\end{array}$ http://dx.doi.org/10.1002/(SICI)1097-0266(199804)19:4<363::AID-SMJ974>3.0.CO;2-H

Schneider-Maunoury, G. (2000). Des petites entreprises très vertes. L'Expansion Management Review, mars, 77-83.

Sharma, S., \& Vredenburg, H. (1998). Proactive corporate environmental strategy and the development of competitively valuable organizational capabilities. Strategic Management Journal, 8(19), 729-753. http://dx.doi.org/10.1002/(SICI)1097-0266(199808)19:8<729::AID-SMJ967>3.0.CO;2-4

Shrivastava, P., \& Hart, S. (1996). Demain l'entreprise durable?. Revue Française de Gestion, Mars-Avril-Mai, 110-122.

Teece, D. J., Pisamo, G., \& Shuen, A. (1997). Dynamic Capabilities and Strategic Management. Strategic $\begin{array}{llll}\text { Management Journal, } & \text { 509-533. }\end{array}$ http://dx.doi.org/10.1002/(SICI)1097-0266(199708)18:7<509::AID-SMJ882>3.0.CO;2-Z

Wacheux, F. (1996). Méthodes qualitatives et recherche en gestion. Paris: Economica, Collection Gestion.

Wernerfelt, B. (1984). A Resource-based View of the Firm. Strategic Management Journal, 5, 171-180. http://dx.doi.org/10.1002/smj.4250050207

Yin, R. (1989). Case study research: Design and methods. Newbury Park: Sage Publishing.

Zollo, M., \& Winter, S. (2002). Deliberate Learning and the Evolution of Dynamic Capabilities. Organization Science, 13, 339-351. http://dx.doi.org/10.1287/orsc.13.3.339.2780 